Розмірковуючи над значенням психоаналізу для педагогіки, А. Фрейд виокремила такі чотири його позитивні сторони: 1) завдяки психоаналізу було обгрунтовано недоліки та слабкі сторони притаманної тому часові освітньої традиції; 2) під впливом психоаналізу було узагальнено наявні знання про складність взаємодії між дітьми і дорослими; 3) психоаналіз створив підгрунтя для виправлення допущених батьками помилок у вихованні дітей; 4) саме психоаналізу належить роль першовідкривача у питанні врегулювання внутрішніх конфліктів між учнями та педагогами [6, с. 55]. Таким чином, на думку А. Фрейд, будь-яку взаємодію з дитиною (навчання, виховання, психокорекція тощо) неможливо уявити без злагодженої емоційної взаємодії, і чим складнішою при цьому є їі мета, тим міцнішою має бути ця взаємодія [4, с. 427].

Висновки. Постать А. Фрейд і сьогодні, на початку XXI століття, залишається однією з ключових у розбудові психоаналітичної педагогіки. Розроблена нею під впливом ідей 3. Фрейда та М. Монтессорі концепція, ставила під сумнів авторитарну педагогіку і класичну систему освіти як таку, що утискала таланти, заперечувала самовираження дитини, закликала до поширення внутрішніх конфліктів. Будучи за фахом учителем молодших класів, Анна Фрейд пропагувала поширення психоаналітичних ідей серед учителів. Свій метод роботи з дітьми вона протиставляла концепції М. Кляйн, розвідки якої стосувалися переважно роботи з немовлятами і дітьми раннього віку.

Зважаючи на вищевикладене, перспективи подальших наших досліджень вбачаємо у вивченні ідей кляйніанського психоаналізу та його внеску в педагогічну практику.

\section{СПИСОК ВИКОРИСТАНОЇ ЛІТЕРАТУРИ}

1. Бурлакова Н. С. Детский психоанализ: школа Анны Фрейд / Н. С. Бурлакова, В. И. Олешкевич. - М. : Издательский центр «Академия», 2005.

2. Бурлакова Н. С. Психоаналитическая педагогика: открытия, надежды и разочарования / Н. С. Бурлакова // Современное дошкольное образование. -2009 . - № 3. - С. 46-52.

3. Энциклопедия глубинной психологи : в 3 т. Т. 3. Последователи Фрейда. - М. : Когито-Центр, МГМ, 2002. - 410 с.

4. Фрейд А. Детский психоанализ / А. Фрейд. СПб. : Питер, 2003. - 477 с.

5. Фрейд А. Война и дети / А. Фрейд, Д. Берлингем ; пер. с англ. Е. Уманской // Развитие личности. - 2004. - № 3. - С. 184-208.

6. Фрейд А. Теория и практика детского психоанализа / А. Фрейд. - М., 1999. - Т. 1. - 384 с.

7. Freud A. Wege und Irrwege in der Kinderentwicklung. - Bern, Stuttgart: Huber und Klett, 1968.

8. Hug-Hellmuth H. Kinderpsychologie und Pädagogik // Jahrbuch für Psycho-analytische und psypathologische Forschungen. - 1914. - № 6. - P. 398.

9. Trabalzini P. Maria Montessori e i rapporti con Sigmund Freud // Annali di storia dell'educazione e delle istituzioni scolastiche. 2018. - № 25. P. 146-162.

Дата надходження до редакиіï: 03.08.2019 р.
УДК 371.2(09)

DOI: $10.37026 / 2520-6427-2019-100-4-88-89$
Ярослав СПІВАК,

кандидат педагогічних наук, доиент кафедри менеджменту ДВНЗ «Донбаський державний педагогічний університет»,

м. Слов'янськ Донеиької області

\title{
АКМЕОЛОГІЧНІ АСПЕКТИ ПРОФЕСІЙНОЇ ПІДГОТОВКИ СОЦАЛЬНИХ ПРАЦІВНИКІВ В УМОВАХ НЕПЕРЕРВНОЇ ОСВІТИ
}

У статті розкрито особливості засвоєння майбутніми сочіальними працівниками теоретичних засад неперервної освіти в ході вивчення курсу «Андрагогіка з основами акмеологї̈. Студенти оволодівають категоріальним апаратом з означеної сфери, усвідомлюють сутність безперервної освіти як системи, щуо охоплюе всі рівні освіти. Важливим при иьому є акмеологічний підхід до педагогічної підготовки майбутніх сочіальних працівників, щчо полягає у виявленні природного потенціалу кожної людини та створенні умов для подальшого вияву їх творчих інтересів та обдарувань.

Ключові слюва: акмеологічний підхід, кониептуальні положення, функції, принщипи, неперервна освіma, особистість.
В статье раскрыты особенности усвоения будуциими социальньыми работниками теоретических основ непрерывного образования в ходе изучения курса «Андрагогика с основами акмеологии». Студенты овладевают категориальным аппаратом с обозначенной сферы, осознают сущность непрерывного образования как системы, охватьвваюей все уровни образования. Важным при этом является акмеологический подход к педагогической подготовки будущиих сочииальных работников, что заключается в выявлении природного потенииала каждого человека и создании условий для дальнейшего проявления их творческих интересов и дарований.

Ключевые слова: акмеологический подход, концептуальные положения, функции, принщипь, непрерывное образование, личность. 
The article reveals the peculiarities of the assimilation by future social workers of the theoretical foundations of continuing education during the study of the course of andragogy with the basics of acmeology. Students acquire the categorical apparatus of this sphere, they realize the essence of continuous education, which is regarded as the main principle of its organization, as a system embracing all levels of education. An important acmeological approach to the pedagogical training of future social workers is to show the natural potential of each person and create conditions for a creative productive turn of her interests, talents. An analysis of the legal framework of documents regulating the activities of higher education institutions, such as: Law of Ukraine "On Education» (2014) and "On Higher Education» (2018), Concepts of Development of Continuing Teacher Education (2013)), The Concepts of Development of Education of Ukraine for the period 2015-2025 (project), the Concepts of Adult Education in Ukraine (2011), the Concepts of Development of Teacher Education (project, 2012), etc. The essence of the concept of «continuous education", which is considered by scientists as a continuous process that stimulates people and allows them to acquire the necessary knowledge, values, skills that contribute to the personal and professional realization and self-realization of a person, improving his skills throughout life, is disclosed. The functions of continuing education: compensating (elimination of gaps of basic education); adaptive (prompt preparation and retraining in the conditions of maintenance of industrial and social situation); developmental (meeting the spiritual demands of the individual and the needs of creative growth) are distinguished. The ways of realization of continuous education are outlined. The principles of organization of the system of continuous education (humanization, continuity, predictability, variability, ability to self-organization and self-development) is determined.

Key words: acmeological approach, conceptual positions, functions, principles, continuous education, personality.

Питання важливості вивчення проблеми професійної підготовки соціальних працівників в умовах неперервної освіти визначається необхідністю привести процес навчання у відповідність до нових вимог суспільства, наповнити його новим змістом, не лише співзвучним із сучасними реаліями освіти, а й спрямованим на випереджуюче реагування на зміни в потребах суспільства. Важливим чинником дієвості такого реформування $\epsilon$ перегляд змісту, форм і методів підготовки фахівців соціальної сфери.

Прогнозування та визначення конкретних шляхів реалізації освіти на сучасному етапі розвитку нашої держави має грунтуватися на врахуванні особливостей, іманентно притаманних як цивілізаційному розвитку загалом, так і взаємодії еволюційних та революційних змін зокрема. Кардинальним змінам у суспільстві відповідають докорінні зміни в підходах до безперервної освіти особистості. Сьогодні заклади вищої освіти (ЗВО) починають працювати в новому законодавчому просторі відповідно до Законів України «Про освіту» (2017 р.) та «Про вищу освіту» (2018 р.), Концепції розвитку неперервної педагогічної освіти (2013 р.), Концепції розвитку освіти України на період 2015 - 2025 рр. (проєкт), Концепції освіти дорослих в Україні (2011 р.), Концепції розвитку педагогічної освіти (проєкт, 2012 р.) тощо.
Постановка проблеми. Реформування системи вищої освіти зумовлює появу в магістерських програмах нових педагогічних дисциплін, серед яких варто виокремити «Андрагогіку з основами акмеології». Майбутні соціальні працівники мають засвоїти теоретичні положення неперервної освіти, спрямовані на розвиток особистості впродовж життя: усвідомлення освіти як процесу, що охоплює все життя людини; постійне цілеспрямоване залучення людини до соціокультурного досвіду, що має здійснюватися на всіх етапах сучасної системи освіти (створення умов для безперервного навчання людини, забезпечення взаємозв'язку і наступності на різних етапах системи освіти). У теорії й практиці безперервної освіти особливий акцент робиться на освіті дорослих за межами базової освіти, а саме: набутті і підвищенні кваліфікації, перепідготовці у процесі зміни професії, освіті у процесі адаптації до зміни соціальних умов.

У зв'язку з цим завданням майбутніх соціальних працівників $€$ всестороннє вивчення поняття «неперервна освіта» як процесу, що включає «навчання впродовж життя», «продовжувану освіту», «довічну освіту», «довічне учіння», «перманентну освіту», «подальшу освіту», «освіту дорослих», «поновлювану освіту» (здобуття освіти «певними частинами» впродовж життя, відхід від практики тривалого навчання у ЗВО, відірваного від трудової діяльності, взаємодія освіти з іншими видами діяльності, наприклад, професійною).

Аналіз наукових досліджень та публікацій. Проблема неперервної освіти вивчалася як зарубіжними (П. Джарвіс, Дж. Кідд, В. Кінг, С. Кортней, П. Ленгранд, М. Ноулс, А. Роджерс, Б. Ананьєв, А. Даринський, С. Змєєв, Т. Колеснікова, Н. Кузьміна), так і вітчизняними (О. Аніщенко, С. Архипова, Л. Лук'янова, Н. Ничкало, Л. Сігаєва, О. Огієнко та ін.) науковцями в різних аспектах - законодавчому, теоретико-методологічному, концептуальному.

Мета статті полягає в аналізі особливостей засвоєння майбутніми соціальними працівниками теоретичних положень неперервної освіти в умовах магістратури в контексті сучасних викликів.

Виклад основного матеріалу. Як відомо, вченими по-різному трактувалося поняття «неперервна освіта». Так, за Н. Ничкало, це неперервний процес, що стимулює людей і дозволяє оволодівати необхідними знаннями, цінностями, навичками, які сприяють особистісній та професійній реалізації й самореалізації людини, підвищенню її кваліфікації впродовж усього життя. Неперервна професійна освіта повинна сприяти утвердженню особистості як найвищої цінності суспільства, виступити гарантом щодо ії знеособлення в умовах ринкової економіки, допомогти самореалізуватися в професійній діяльності, реалізувати гуманістичну спрямованість сучасної освіти [7, с. 13].

О. Владиславлєв, фахівець у даній сфері, зазначає: «На жаль, сьогодні мало хто усвідомлює, що неперервна освіта вимагає принципово нових підходів до організації всієї системи освіти» [4].

На думку Л. Лук'янової, «мета освіти впродовж життя полягає у цілісному розвитку особистості, підвищенні іiі професійної й соціальної адаптації у швидкозмінюваному сучасному суспільстві; розвитку іiї здатностей і можливостей, де ключову позицію посідає саме людина, її особистість, бажання й прагнення постійного розвитку» [5, с. 9].

Проблематику неперервної освіти можна умовно поділити на дві сфери. Перша пов'язана з побудовою 
неперервної освіти як частини соціальної практики (соціальний аспект неперервної освіти), друга - iз самим процесом освоєння людиною нового життєвого, соціального досвіду (психолого-педагогічний аспект неперервної освіти).

У науковій літературі виокремлюють такі функції неперервної освіти: компенсуюча (ліквідація прогалин базової освіти); адаптивна (оперативна підготовка й перепідготовка в умовах забезпечення виробничої та соціальної ситуації); розвивальна (задоволення духовних запитів особистості та потреб творчого зростання) [1;2]. При цьому шляхи реалізації неперервної освіти охоплюють усю сферу запитів формальної освіти, зокрема державну освітню систему, приватні навчальні заклади, очне, вечірнє та заочне навчання, а також «дистанційну освіту» (засоби поштового зв'язку, теле- і радіокомунікації, комп'ютерного доступу до банків інформації телефонними каналами та ін.), що пов'язано зі зростанням рівня інформатизації суспільства, розширенням можливостей доступу до різних інформаційних фондів.

Для майбутніх соціальних працівників важливим $€$ акмеологічний аспект неперервної освіти, а саме допомога педагогів, андрагогів у визначенні природного потенціалу кожної людини, створення умов для максимального розвитку цього потенціалу, адже людина може отримувати задоволення лише від такої роботи, яка відповідає їі потребам, інтересам, схильностям, обдаруванням. Тому для психолого-педагогічних досліджень важливою сферою проблематики неперервної освіти є питання самоактуалізації людиною власних цінностей і творчого потенціалу в освітньому процесі [6]. Неперервна освіта в іiї широкому розумінні не обмежується термінами, простором, місцем та методами учіння; вона об'єднує всю діяльність і ресурси у сфері освіти, спрямована на досягнення гармонійного розвитку потенціалу особистості та прогресу в перетворенні суспільства.

Водночас неперервна освіта розглядається не лише як засіб зв'язку та інтеграції елементів наявної системи освіти, а й як основоположний принцип організаційної перебудови різних ланок світи. Для майбутніх соціальних працівників при цьому вагомими є иіннісні характеристики неперервної світи: гуманізм; демократизм (рівність доступу); всезагальність (включеність усього населення до різних структур і рівнів освіти); інтеграція (формальних і неформальних структур традиційного і нового типу); гнучкість (навчальних планів і програм, способів організації навчального процесу); варіантність стратегій учня, зв'язок із життям індивіда, професійною і соціальною діяльністю.

В основу побудови системи неперервної освіти мають бути покладені такі передумови, які мають засвоїти майбутні соціальні працівники: різні, але адекватні для кожного члена суспільства можливості отримання загальної та професійної освіти, що відображають його соціальні наміри, професійні інтереси та максимально задовольняють індивідуальні, духовні, інтелектуальні потреби особистості; рівноцінність у часі навчання в різних навчальних закладах для отримання відповідного рівня освіти (професійного), а також наявність принципової можливості нетрадиційних шляхів одержання освіти (наприклад, екстернат) при обов'язковому забезпеченні належного рівня професійної компетентності; завершеність освіти на кожному рівні підготовки до професійної діяльності, що, з одного боку, забезпечує рівень професійної компетентності, необхідний для активного вступу в трудову діяльність (швидку адаптацію), а $з$ іншого формує фундамент і «необхідність» для подальшого професійного вдосконалення; гнучкість організаційних форм професійної підготовки, перепідготовки, підвищення кваліфікації, їх спрямованість на вирішення освітніх завдань при максимальній економії ресурсів системи (інтеграція, центри колективного користування тощо).

В умовах магістратури студенти покликані оволодівати такими принципами організації системи неперервної освіти:

- гуманізація - орієнтація всіх підсистем (починаючи із дошкільної освіти) на формування різнобічної гармонійно розвиненої особистості, на виховання розмаїття індивідуальностей, що передбачає діалогічність і диференціацію навчально-виховних систем, розгляд загальної освіти як мети і засобу всіх підсистем, гуманізацію навчальних дисциплін (природничо-наукових, соціально-культурних, технічних і технологічних циклів);

- наступність - відображення на кожному рівні освіти перспективних вимог наступних її ланок і системи освіти в цілому; розгляд кожного рівня освіти як моменту переходу від попереднього рівня до наступного;

- прогностичність - орієнтація навчально-виховних цілей системи освіти не лише на актуальні й перспективні вимоги соціального замовлення, а й на актуальні та перспективні потреби, що розвиваються, пізнавальні здібності особистості;

- варіативність - можливість досягнення цілей освіти в різних формах і режимах (часових і просторових);

- здатність до самоорганізаиії і саморозвитку виявляється в гнучкості та адаптивності навчально-виховних систем, здатності перебудовуватися, переходити на новий режим функціонування залежно від обставин, що змінюються, а за необхідності - впливати на ці обставини, перетворювати ïx $[2$, с. $42 ; 3]$.

Таким чином, неперервна освіта дорослих $є$ важливою умовою розвитку особистості й суспільства, підсистемою загальної системи неперервної освіти, іiі відносно відокремленим підрозділом, основне завдання якого - сприяти всебічному розвитку людини в період іiї самостійного життя. Саме завдяки цьому освіта дорослих $є$ соціальним інститутом, який забезпечує довічне збагачення творчого потенціалу особистості.

Отже, процес засвоєння майбутніми соціальними працівниками теоретичних аспектів неперервної освіти у ході вивчення курсу «Андрагогіка 3 основами акмеології» передбачає врахування акмеологічних умов системи ціложиттєвого навчання, що сприяє їх особистісно-професійному зростанню. До таких умов варто віднести: врахування принципів організації безперервної освіти; упровадження суб' єктного підходу, пов'язаного 3 розвитком природного потенціалу і творчих здібностей майбутнього соціального працівника, що дають йому змогу вибудовувати продуктивні стратегії життєвого шляху; 
посилення інтеграційної ролі андрагогічного й акмеологічного супроводу як цілісного і безперервного процесу вивчення, розвитку, саморозвитку пізнавальної сфери й особистості майбутнього соціального працівника, розробку і реалізацію відповідного змісту, моделей, технологій неперервної освіти.

Висновки. Зважаючи на вищевикладене, підсумуємо: засвоєння майбутніми соціальними працівниками теоретичних засад неперервної освіти передбачає моделювання розвивального акмеологічного середовища, що створює не лише теоретико-методологічне підгрунтя для розгортання наукового пошуку в сфері андрагогічної та акмеологічної проблематики, а й передбачає забезпечення ефективних умов для особистісного і професійного зростання особистості майбутнього соціального працівника, досягнення ним акме-вершин у сфері професійної майстерності.

\section{СПИСОК ВИКОРИСТАНОЇ ЛІТЕРАТУРИ}

1. Алибекова Г. 3. Учебно-педагогические комплексы в системе непрерывного образования / Г. 3. Алибекова // Советская педагогика. - 1992. № 9,10. - С. 54-60.
2. Ананьев Б. Г. О проблемах современного человекознания / Б. Г. Ананьев. - М. : Наука, 1977. - 379 с.

3. Антов Н. А. Непрерывное образование и вуз / Н. А. Антов. - М. : Наука, 1989.

4. Владиславлев А. П. В поисках концепции / А. П. Владиславлев // Вестник высшей школы. 1989. - № 26. - С. 48-50.

5. Концепція освіти дорослих в Україні / укл. Л. Б. Лук'янова. - Ніжин : ПП Лисенко М. М. 2011. -24 c.

6. Кузьмина Н. В. Акмеология качества профессиональной деятельности специалиста : монография / Н. В. Кузьмина, С. Д. Пожарский, Л. Е. Паутова. Санкт-Петербург ; Коломна ; Рязань, 2008. - 376 с.

7. Ничкало Н. Г. Неперервна професійна освіта як філософська та педагогічна категорія / Н. Г. Ничкало // Неперервна професійна освіта: теорія і практика. - 2011. - Вип. 1. - С. 9-22.

8. Освіта дорослих: теоретичні та методологічні засади : [монографія] / авт. кол. : Л. Б. Лук'янова, Л. С. Сігаєва, О. В. Аніщенко та ін. - К. : Педагогічна думка, 2012. -420 с.

Дата надходження до редакиї: 26.07.2019 p.

Наталія СУШИК,

кандидат педагогічних наук, доиент кафедри соиіальної роботи та педагогіки вищзої школи Східноєвропейського національного університету імені Лесі Українки, м. Луиьк

\section{КОМПЕТЕНТНІСНИЙ ПІДХІД У РЕАЛІЗАЦІЇ ТЕХНОЛОГІЇ ФОРМУВАННЯ ЗДОРОВОГО СПОСОБУ ЖИТТЯ ДІТЕЙ ПІДЛІТКОВОГО ТА ЮНАЦЬКОГО ВІКУ З ВИКОРИСТАННЯМ МЕТОДУ «РІВНИЙ - РІВНОМУ»}

У статті визначено сутність та ознаки технологї соиіального виховання особистості. Розроблено характеристику технології формування здорового способу життя дітей підліткового та юнацького віку з використанням методу "рівний - рівному» на основі компетентнісного підходу. Запропоновано практичні рекомендації для сочіальних педагогів $i$ фахівиів із соиіальної роботи з метою підвищення ефективності застосування означеної технологї.

Ключові слова: сочіальне виховання, технологіі соиіального виховання, соиіальний досвід особистості, компетентнісний підхід, компетентність, компетениія, здоров'язбережувальна, комунікативна, правова, життєва компетентності особистості, технологія формування здорового способу життя дітей підліткового та юнацького віку з використанням методу «рівний - рівному».

В статье определень сущиность и признаки технологии социального воспитания личности. Охарактеризована технология формирования здорового образа жизни детей подросткового и юношеского возраста с использованием метода «равный - равному» на основе компетентностного подхода. Предложены практические рекомендации для сочиальных педагогов и специалистов по сочиальной работе $c$ иелью повышения эффективности применения этой технологии. 